\title{
Keep Your Politics Out of My Practice
}

"Nothing so needs reforming as other people's habits. Fanatics will never learn that, though it be written in letters of gold across the sky."

-Mark Twain

Politicians have repeatedly inserted themselves into exam rooms and under hospital gowns, telling doctors what they can and cannot discuss with patients; forcing providers to recite scripted medical advice they know to be factually inaccurate; and even instructing physicians to prioritize the financial interests of private companies over the health of their patients $(1,2)$.

In 2011 Florida passed a sweeping law barring doctors from routinely asking patients whether they had guns in their homes, counseling them on common-sense firearm storage measures or recording any information about gun ownership in their medical files. Four states (Pennsylvania, Ohio, Colorado, and Texas) have passed legislation relating to disclosure of information about exposure to chemicals used in the process of hydraulic fracturing ("fracking"). Some new laws require physicians to discuss specific practices that may not be necessary or appropriate at the time of a specific encounter with a patient. For example, New York enacted legislation in 2010 that requires physicians and other health care practitioners to offer terminally ill patients "information and counseling regarding palliative care and end-of-life options appropriate to the patient, including ... prognosis, risks and benefits of the various options; and the patient's legal rights to comprehensive pain and symptom management." Still other laws would require physicians to provide - and patients to receive - diagnostic tests or medical interventions whose use is not supported by evidence, including tests or interventions that are invasive and required to be performed even without the patient's consent. In Virginia, a bill requiring women to undergo ultrasonography before having an abortion was passed despite objections from the American College of Physicians. Arizona required physicians to tell women that drug-induced abortions may be "reversible" a claim that is unsupported by scientific evidence. A growing number of states have instituted mandatory waiting periods for abortions when there is no apparent medical need.

Healthcare providers who do not observe with these laws could face fines, license revocation, and even jail time for failure to comply. Fortunately, many have been struck down by the courts. However, a new tact for some has been to allow objection to certain types of medical treatment such as abortions based on the healthcare provider's religious or moral beliefs. These providers have a new defender in the Trump administration (3). The top civil rights official at the Department of Health and Human Services (HHS) is creating the Division of Conscience and Religious Freedom to "protect" doctors, nurses and other health care workers who refuse to take part in procedures like abortion or treat certain people because of moral or religious objections. "Never forget that religious freedom is a primary freedom, that it is a civil right that deserves enforcement and respect," said Roger Severino, an anti-abortion Catholic lawyer who directs HHS's Office for Civil Rights. Here in Arizona healthcare 
professionals are not required to provide services that conflict with their religious beliefs, including abortion, abortion-inducing medication, emergency contraception, end of life care, and collection of umbilical cord blood (4).

Two recent incidents in Arizona involving pharmacists have brought this law under scrutiny (5). Hilde Hall, a transgender woman in Arizona, was allegedly denied hormone prescriptions by a CVS pharmacist in Fountain Hills. She was unable to fill the prescription at that location and despite her doctor requesting it, the pharmacist refused to transfer the order. CVS apparently fired the pharmacist. This comes within weeks of the case of Nicole Arteaga, who was denied medication for a nonviable pregnancy by a Walgreens pharmacist in Peoria, Brian Hreniuc PharmD. The Arizona State Board of Pharmacy has agreed to review Ms. Arteaga's complaint against Dr. Hreniuc.

The Arizona Republic put it well. "The person in the white coat behind the counter should be there to help. To answer questions and ensure that the patient understands what the medicine is, how to take it and is aware of possible side-effects. Not to humiliate, question or refuse to serve the client" (5). Assuming the accounts in the Arizona Republic are accurate, both pharmacists committed several transgressions of the code of ethics of the American Pharmacists Association including a commitment to the patient's welfare; protecting the dignity of the patient; serving the patient in a private and confidential manner; respecting the autonomy and dignity of each patient; promoting the right of self-determination; recognizing individual self-worth; and acknowledging that colleagues and other health professionals may differ in the beliefs and values they apply to the care of the patient (6).

Whether the Arizona State Board of Pharmacy will decide to enforce professional standards or uphold a politically motivated law is unclear. At a time when pharmacists seek to extend their scope of practice, the behavior of these two pharmacists make one question who they would serve if given more responsibility-the patient or themselves? Also disappointing has been the lack of condemnation from other pharmacists and pharmacy professional groups such as the Arizona Pharmacists Association. This lack of action makes expansion of the scope of practice questionable. We as healthcare providers are entitled to our politics just like anyone else but the line is crossed when you impose your politics on me or my patients.

Richard A. Robbins, MD*

Editor, SWJPCC

\section{References}

1. Weinberger SE, Lawrence HC 3rd, Henley DE, Alden ER, Hoyt DB. Legislative interference with the patient-physician relationship. N Engl J Med. 2012 Oct 18;367(16):1557-9. [CrossRef] [PubMed]

2. Rampell C. Politicians are invading our medical exam rooms. Washington Post. October 19, 2015. Available at: https://www.washingtonpost.com/opinions/politicians-playing- 
doctor/2015/10/19/7b1af280-769e-11e5-bc809091021aeb69 story.html?utm term=.ae6df6d65643 (accessed 7/22/18).

3. Kodjak A. Trump admin will protect health workers who refuse services on religious grounds. NPR. January 18, 2018. Available at: https://www.npr.org/sections/healthshots/2018/01/18/578811426/trump-will-protect-health-workers-who-reject-patientson-religious-grounds (accessed 7/22/18).

4. Center for Arizona Policy. Arizona religious freedom laws. January 2014. Available at: http://www.azpolicypages.com/religious-liberty/arizona-religious-liberty-laws/ (accessed 7/22/18).

5. Price TF. CVS pharmacist who refused transgender patient's prescription abused Arizona law. Arizona Republic. July 20, 2018. Available at:

https://www.azcentral.com/story/opinion/op-ed/2018/07/20/hilde-hall-transgenderprescription-denied-cvs-pharmacy/809450002/ (accessed 7/22/18).

6. American Pharmacists Association. Code of Ethics. October 27, 1994. Available at: https://www.pharmacist.com/code-ethics (accessed 7/22/18).

* The views expressed are the author's and do not necessarily represent those of the American Thoracic Society or its affiliates. 